\title{
The Price of Unification The Emergence of Health \& Welfare Policy in Pre-Bismarckian Prussia
}

\author{
Fritz Dross
}

\section{Introduction}

$S^{\text {ing }}$ till the German model of a "welfare state" based on compulsory health insurance is seen as a main achievement in a wider European framework of health and welfare policies in the late 19th century. In fact, health insurance made medical help affordable for a steadily growing part of population as well as compulsory social insurance became the general model of welfare policy in 20th century Germany. Without doubt, the implementation of the three parts of social insurance as 1) health insurance in 1883;2) accident insurance in 1884; and 3) invalidity and retirement insurance in 1889 could stand for a turning point not only in German but also in European history of health and welfare policies after the thesis of a German "Sonderweg" has been more and more abandoned. ' On the other hand, recent discussion seems to indicate that this model of welfare policy has overexerted its capacity. ${ }^{2}$ Economically it is based on insurance companies with compulsory membership. With the beginning of 2004 the unemployment insurance in Germany has drastically shortened its benefits and was substituted by social

1 Young-sun Hong, "Neither singular nor alternative: narratives of modernity and welfare in Germany, 1870-1945", Social History 30 (2005), pp. 133-153.

2 To quote just one actual statement: "Is it cynically to ask why the better chances of living of the well-off should not express themselves in higher chances of survival? If our society gets along with (social and economical) inequality it should accept (medical) inequality." H.-O. Wiesemann, "Editorial", in Zeitschrift für Versicherungsmedizin 57 (2005), p. 62 (translation by FD). For the broader discussion (in Germany) see e.g.: Aus Politik und Zeitgeschichte 8-9 (2006); Aus Politik und Zeitgeschichte 29-30 (2002); Das Soziale neu denken. Für eine langfristig angelegte Reformpolitik. Die deutschen Bischöfe. Kommission für gesellschaftliche und soziale Fragen. Bd. 28, 12. Dezember 2003. 
welfare in wide areas of its former competence. ${ }^{3}$ The actual discussions both on health and retirement insurance point to the same direction of redefining the border between social risks to be coped with by the individual on its own and those burdened by the general public in a strictly organised and mandatory manner. Thus, it might be helpful to take a look back to understand how these borders had developed in the process of an emerging Prussian "welfare state" in the course of the 19 th century. ${ }^{4}$

In order to give a concise, but narrow, overview, the following paper is going to concentrate on the Prussian development as mirrored by Prussian legislation. ${ }^{5}$ Doing so, one has to be aware of two crucial points, which have lead to essential misunderstandings: 1) By no means Prussia should be mistaken for "Germany" whatever should be named by this term with respect to 19th century historical developments. 2) Even the kingdom of Prussia was far away from a uniform state in terms of territory or legislation, not to mention the socio-economical development, socio-cultural aspects or mentality. In the course of the 19th century Prussia comprised different territories with different state of industrialisation and even different laws while steadily growing by incorporating smaller territories: ${ }^{6}$

As consequences of the Silesian and the Seven Years' War (1740-1763), Prussia gained and consolidated Silesia; it appropriated West Prussia, South Prussia, New East Prussia, Ermland, the Netz district, as well as Danzig and Thorn following the Divisions of Poland (1772-1795). The suspension of the ecclesiastical principalities by the Reichsdeputationshauptschluss in 1803 bestowed the kingdom with significant territorial gains in central Germany (the dioceses of Hildesheim, Paderborn, as well as large parts of Münster and parts of Mainz (Thuringia); the imperial abbeys in Essen, Herford, Quedlinburg, Elten, Werden and Cappenberg; the free cities Mühlhausen, Nordhausen and Goslar). Having lost large parts of its territory in the Treaty of Tilsit (1807), Prussia emerged from the Congress of Vienna as one of the biggest winners in the political reorganisation of Europe in the post-Napoleonic era. After gaining the kingdom of Hanover as well as Schleswig-Holstein, Nassau, Hesse-Kassel and Frankfurt (1866-67), the Prussian monarchy comprised approximately two-thirds of the territory and three-fifths of the population of the Second Empire at its founding in 1871. Thus, Prussian unification was not only an

3 Cf. Aus Politik und Zeitgeschichte 16 (2005).

4 Cf. Florian Tennstedt, "Sozialwissenschaft - Sozialrecht - Sozialgeschichte. Kooperation und Konvergenz am Beispiel der Sozialpolitik“, in G. Schulz et. al., eds., Sozial- und Wirtschaftsgeschichte. Arbeitsgebiete - Problem - Perspektiven (Stuttgart, 2004), pp. 551-575.

5 Cf. Fritz Dross, "Health Care Provision and Poor Relief" in Enlightenment and 19th Century Prussia, in O. P. Grell, A. Cunningham, R. Jütte, eds., Health Care and Poor Relief in 18th and 19th Century Northern Europe (Aldershot 2002), pp. 69-111.

6 Cf. Gerhard Köbler, Historisches Lexikon der deutschen Länder. Die deutschen Territorien und reichsunmittelbaren Geschlechter vom Mittelalter bis zur Gegenwart, (5th ed. Munich, 1995), pp. 477-480. 
important prerequisite but set the pace for German unification until the foundation of the (Prussian-) German Empire in 1871.

From this perspective the following paper is going to analyse central legislation with respect to health and social welfare policy. Of course, this method is incapable to show the (historical) social reality of poverty and disease. But legislation could be seen as a central - if not the most important - mean of the politics of unification in 19th century Prussia, which had to counter the differing local and regional situations with a uniform reaction of the state. At the same time it becomes possible to take a look at legislation dedicated to several spheres of unification policy but carrying out diverse consequences in the field of unifying health and welfare conditions for the whole Prussian population.

\section{The role of health and welfare regulations in Prussian state-building}

In Prussia poor relief became a general responsibility of the state in the framework of the General Prussian Code (Allgemeines Landrecht) of $1794 .^{8}$ In effect, the responsibilities of local communities, especially the municipalities, were laid down by the state. Central government did not in any way commit itself to the extension of benefits, but only provided the legal parameters of poor relief carried out by local communities. The communities, for their part, were explicitly not obliged to give welfare provision vis-à-vis the poor, but rather vis-à-vis the state. The Allgemeines Landrecht fundamentally followed a principle of poor relief by which the community of origin, usually the place of birth, determined the relief agency. To enable labour migration obviously demanded to reach a state of unification of poor relief provision and administration beyond that, which was one of the major aims in Prussian welfare policy for over three quarts of the 19th century.

Communalisation of the welfare system meant to locate the problem in the cities and communities. These were required by the Prussian state to solve the social problem arising from poverty. The Municipal Code (Städteordnung) of $1808^{9}$

7 The Sources are edited in a substantial and exemplary publication series: Quellensammlung zur Geschichte der deutschen Sozialpolitik: 1867 bis 1914. Im Auftrag der Historischen Kommission der Akademie der Wissenschaften und der Literatur, Mainz, begründet von Peter Rassow. Karl Erich Born et al. (eds.), Wiesbaden (Stuttgart, Darmstadt) 1966 et sqq.

8 Allgemeines Landrecht für die Preußischen Staaten von 1794. Textausgabe. Mit einer Einführung von Hans Hattenhauer und einer Bibliographie von Günther Bernert (Frankfurt/M., Berlin, 1970); Reinhart Koselleck, Preußen zwischen Reform und Revolution. Allgemeines Landrecht, Verwaltung und soziale Bewegung von 1791 bis 1848. (2. ed. Stuttgart, 1975), pp. 23149.

9 Ordnung für sämmtliche Städte der Preußischen Monarchie mit dazu gehöriger Instruktion, Behuf der Geschäftsführung der Stadtverordneten bei ihren ordnungsgemäßen 
compelled the municipalities to establish communal authorities on a uniform, corporate legal basis, while the state withdrew completely from the welfare system. The principles of late-absolutist administrative poor relief did, in fact, fundamentally contradict the new early industrial social order, just as the liberal economic policy contradicted the conservative domestic and welfare policy. Freedom of movement and contractual freedom as a foundation of commercial freedom were irreconcilable with the principle only to admit those to poor relief benefits, who were born at the place where they fell ill and got needy.

On 31st December of 1842, the law on the incorporation of newly arrived individuals theoretically superseded the "home principle of poor relief" (Heimatprinzip) in Prussia, ${ }^{10}$ which had been an object of discussion already since 1824. It introduced more or less unlimited freedom of movement and commercial freedom of settlement for any individual not being dependent on public relief. Poor relief was adapted to these new conditions with the law on the obligation of poor relief of the same day, 31st December 1842. ${ }^{11}$ If no other obligated parties, such as relatives, could be drawn upon, then the registered domicile was obliged to assist the poor person. But a paradigmatic shift in Prussian poor law, theoretically intended, did not come along with the new poor law. In fact it excluded those sections of the population who were most in need of it - servants, journeyman and factory workers. In questionable cases the legislature gave the municipal governments the option to treat every impoverished person as a beggar or a vagrant. A law on the punishment of vagrants, beggars and the slothful was passed on 6th January $1843,{ }^{12}$ one week after the two laws just mentioned.

The Municipal Code of $1853,{ }^{13}$ as well as the amendment of the poor law in $1855,{ }^{14}$ laid down that poor relief should begin only after one year in residence at a new location. Any benefits before then had to be extended at the cost of the

Versammlungen. Vom 19ten November 1808; cf. Wolfgang R. Krabbe, Die deutsche Stadt im 19. und 20. Jahrhundert (Göttingen, 1989), pp. 10-14.

10 Gesetz über die Aufnahme neu anziehender Personen, 31. December 1842.

11 Gesetz über die Verpflichtung zur Armenpflege, 31. December 1842.

12 Gesetz über die Bestrafung der Landstreicher, Bettler und Arbeitsscheuen, 6. January 1843; W. G. von der Heyde, Staats- und Orts-Angehörigkeits- und Armenverpflegungs-Verhältnisse, so wie polizeiliche Behandlung der Bettler, Landstreicher und Arbeitsscheuen. Geordnet durch die Gesetzgebung der Jahre 1842 und 1843, die darauf bezüglichen Ministerial-Rescripte und die aus der ältern Gesetzgebung noch zur Anwendung kommenden Vorschriften, (Magdeburg, 1844); W. Dittmar, Die Gesetze vom 31. Dezember 1842 und 56. Januar 1843 ... nebst den dieselben ergänzenden und erläuternden Gesetzen, Verordnungen, Ministerial-Reskripten und Judikaten des Ober-Tribunals und des Gerichtshofes zur Entscheidung der Kompetenz-Konflikte ... (Magdeburg, 1862).

13 Städte-Ordnung für die sechs östlichen Provinzen der Preußischen Monarchie, 30. May 1853.

14 Gesetz zur Ergänzung der Gesetze vom 31. Dezember 1842 über die Verpflichtung zur Armenpflege und die Aufnahme neu anziehender Personen, 21. May 1855. 
"community of origin", usually the place of birth. In case of incapacitating illness, the municipalities were definitely obligated to carry the costs of lost wages for at least three months. In those towns and cities where no wealthy, old foundations could be called upon, the share of the entire municipal budget expended on poor relief exceeded half of the cities' total expenditures and, at times, even comprised two-thirds. ${ }^{15}$

As a consequence, early forms of health insurance were less concerned with the risk of illness as such, but rather with the risk of impoverishment arising from the inability to work. Private and independent health insurance and burial funds became common in the 1840ies and 1850ies. These insurances and funds were private insurance associations based on reciprocity. In fact, workers and craftsmen were often forced to join these associations by labour contracts, factory rules and guild regulations.

In the Prussian case one has to take into account the extreme differences between the old Prussian territories in the east and the Rhenish and Westphalian industrial zones in the west. Even though the population density in entire Prussia nearly tripled between 1816 and 1910, it was lower than in the German Reich (after 1871). Only the provinces Silesia, Saxony, Westphalia and Rhenania exceeded the Prussian and the "German" average in every socio-economic parameter pointing to industrialisation and urbanisation.

For the first time the Prussian central legislation allowed for commercial support organisations at a local level in 1845. This was done in the Prussian Industrial Code (Gewerbeordnung). ${ }^{16}$ In a supplementary directive of February 1849 this was expanded to include factory workers in addition to journeymen and assistants. ${ }^{17}$

The municipalities were allowed to force the individuals in question to join an insurance organisation, as well as to demand contributions to these organisations from the factories, although this was seldom done in practice. A completely new perspective on the problem was opened by the commission concerned with the law on commercial support organisations (Unterstützungskassen) in 1854 by stating that a workers' income should nourish him not only in times of health, but also in times

15 Wolfgang R. Krabbe, Die deutsche Stadt im 19. und 20. Jahrhundert (Göttingen, 1989), 99-107; Jürgen Reulecke, Geschichte der Urbanisierung in Deutschland (Frankfurt/M., 1985), p. 212, tab. 9; Wolfram Fischer, Jochen Krengel, Jutta Wietog, eds., Sozialgeschichtliches Arbeitsbuch. Vol. 1: Materialien zur Statistik des Deutschen Bundes 1815-1870 (Munich, 1982), p. 212; F. J. Benzenberg, Die Gemeinde-Ausgaben der Städte Düsseldorf, Elberfeld, Coblenz, Trier, Berlin und Paris. (1833, 2nd ed. 1835); Alfred Emminghaus (ed.), Das Armenwesen und die Armengesetzgebung in europäischen Staaten (Berlin, 1870), p. 62.

16 Allgemeine Gewerbeordnung, 17. January 1845.

17 Verordnung, betreffend die Errichtung von Gewerberäthen und verschiedene Abänderungen der allgemeinen Gewerbeordnung, 9. Februar 1849. 
Figure 1. Inhabitants per square kilometre in different Prussian regions.

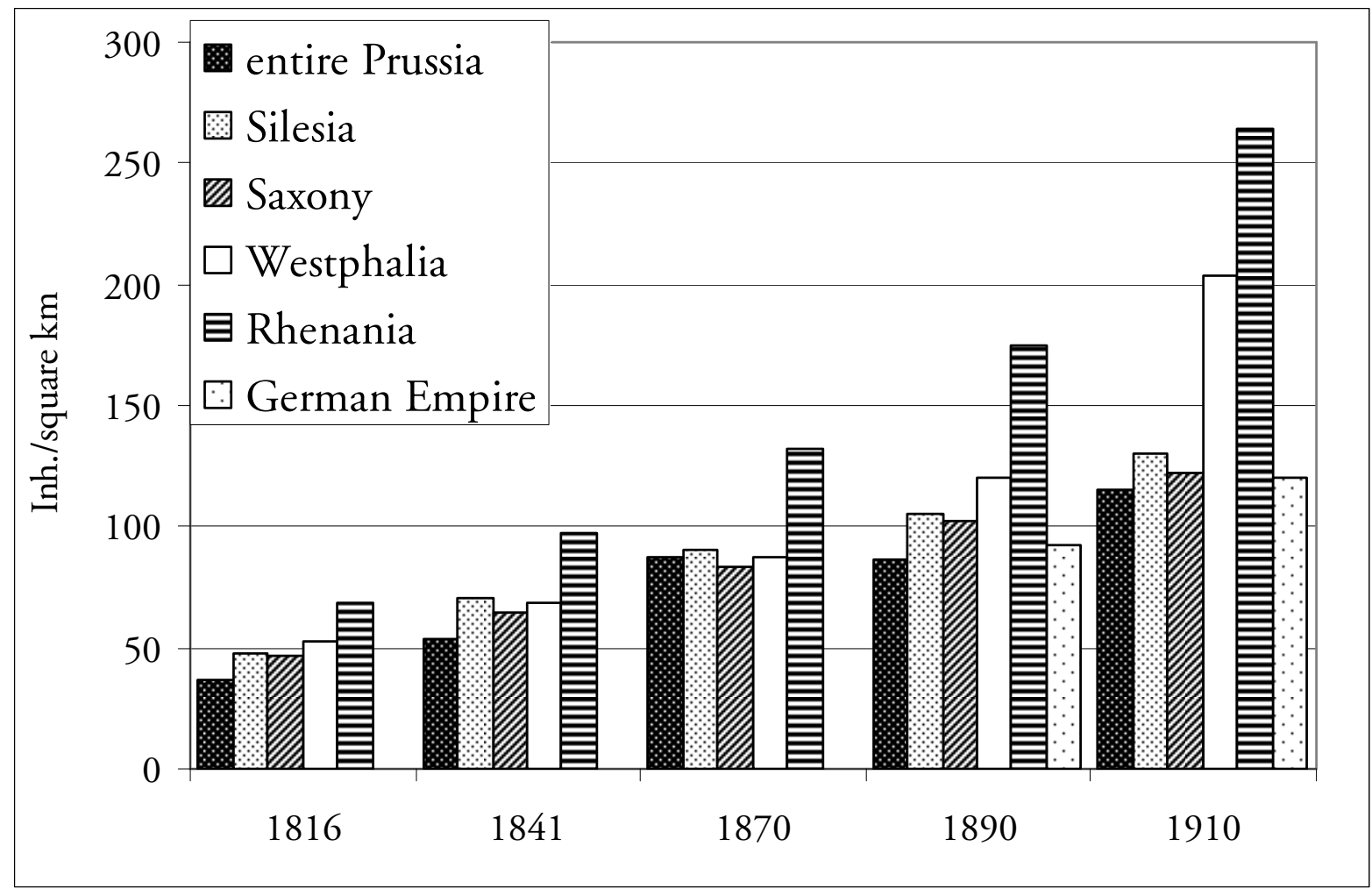

Source: Jürgen Reulecke, Geschichte der Urbanisierung in Deutschland (Frankfurt/M., 1985), p. 201.

of illness. ${ }^{18}$ Through this law the regional governments (Bezirksregierungen) were empowered to introduce mandatory membership when needed. It did not call for compulsory insurance in general, but rather for mandatory membership for certain professional groups. A comparison with the kingdom of Bavaria ${ }^{19}$ shows that in Bavaria early forms of health insurance paying hospital treatment for artisans, journeymen and domestic servants have been proved for two dozen towns as early as 1811 . The members had to pay an entrance fee and weekly contributions for the entitlement to free medical care, usually in local hospitals. In 1850 a Bavarian government ordinance obliged the communes to provide health care measures for a

18 Gesetz, betreffend die gewerblichen Unterstützungskassen, 3. April 1854; Ludwig Puppke, Sozialpolitik und soziale Anschauungen frühindustrieller Unternehmer in Rheinland-Westfalen (Köln, 1966); Ute Frevert, Krankheit als politisches Problem 1770-1880 (Göttingen, 1984), pp. 151-174; Margaret Asmuth, Gewerbliche Unterstützungskassen in Düsseldorf (Köln, 1984), p. 19.

19 Cf. Michael Stolberg, "Health care provision and poor relief in the Electorate and Kingdom of Bavaria”, in O. P. Grell, A. Cunningham, R. Jütte, eds., Health Care and Poor Relief in 18th and 19th Century Northern Europe (Aldershot 2002), pp. 112-135; Eva Brinkschulte, "Die Institutionalisierung des modernen Krankenhauses im Rahmen aufgeklärter Sozialpolitik", in A. Labisch, R. Spree, eds., "Einem jeden Kranken in einem Hospitale sein eigenes Bett". Zur Sozialgeschichte des Allgemeinen Krankenhauses in Deutschland im 19. Jahrhundert (Frankfurt/M., New York, 1996), pp. 187-207. 
period of 90 days for servants, day labourers and factory workers who would not have been entitled to poor relief according to the Heimatrecht, which was effective in Bavaria until 1916.

Beneath industrial policy, however, sanitary police was an important field of legislation. The measures taken against epidemics were primarily concerned with the prevention of cholera. Although not the prevalent cause of death at all, cholera came to be seen as a 'scandalised illness' which contained various interpretations. The early 1830ies showed with dramatic clarity, that neither military cordons nor medicine could do much to counter the march of cholera. Hence, avoiding cholera meant protecting oneself from its potential carriers, the poor, who consequently were placed under tighter control and supervision.

Following the cholera epidemics the Prussian government introduced a number of new laws dealing with public health. The Prussian Hygiene Regulation (Regulativ über die sanitäts-polizeilichen Vorschriften bei den am häufigsten vorkommenden ansteckenden Krankheiten) of 1835 provided the framework for public preventive measures during future epidemics. ${ }^{20}$ In the case of acute epidemics the aim was to quickly isolate a maximum number of affected individuals respectively those suspected of being infected.

By the 1850ies many Prussian cities had introduced a decentralised and nonuniform system of municipal poor relief by relying on voluntary bourgeois activities. This system was based on the subdivision of the cities into as many welfare districts as possible. Towards the end of the century volunteer activity had shifted to the bourgeois' associations and clubs while the municipal administrations adopted welfare systems administered by full-time employees. These employees occasionally developed detailed concepts of a genuine communal social policy as a part of a general system of public services. These developments have been called the emergence of the "welfare city". ${ }^{21}$ Furthermore, municipal servants, engineers and doctors developed a programme of urban sanitary reform. The practice of hygiene in urban public buildings and houses, in factories and commercial zones, the removal of garbage, burials, food inspection, water supply and waste-water

20 Allerhöchste Kabinetsorder (8. August 1835), womit das Regulativ über die sanitätspolizeilichen Vorschriften bei den am häufigsten vorkommenden ansteckenden Krankheiten bestätigt wird; Sanitäts-polizeiliche Vorschriften bei den am häufigsten vorkommenden ansteckenden Krankheiten. Barbara Dettke, Die asiatische Hydra. Die Cholera von 1830/31 in Berlin und den preußischen Provinzen Posen, Preußen und Schlesien (Berlin, New York, 1995); Olaf Briese, Angst in den Zeiten der Cholera (4 vol.s, Berlin, 2003).

21 Cf. Jürgen Reulecke, ed., Die Stadt als Dienstleistungszentrum. Beiträge zur Geschichte der "Sozialstadt" in Deutschland im 19. und frühen 20. Jahrhundert (St. Katharinen, 1995); Jürgen Reulecke, Geschichte der Urbanisierung in Deutschland (Frankfurt/M., 1985), pp. 62-67, pp. 118-131; Wolfgang R. Krabbe, Die deutsche Stadt im 19. und 20. Jahrhundert (Göttingen, 1989), pp. 99-128. 
management - all of these created the hygienic technological infrastructure of the (industrial) cities. ${ }^{22}$

The state of Prussia found itself increasingly unable to manage the challenge of poverty by means of an uniform legislation. In this respect the Prussian state was not unique. Spectacular accidents involving labourers caused public fear and awareness. Consequently the protection of workers became part of the agenda of state politics. However, Bismarck opposed the legislation on the protection of workers. ${ }^{23} \mathrm{He}$ thought that the personal freedom of workers to earn their living (e.g. by doing dangerous jobs) should not be limited by unnecessary legislation. A civil law compensation failed because the basic idea of the employers' general risk liability and that of presumptive guilt of the employer was incompatible with liberal economics and the personal legal comprehension of Chancellor Bismarck.

On another level, these considerations were connected with the so-called internal establishment of the new German Reich (Innere Reichsgründung). ${ }^{24}$ Correspondingly, the Imperial Address of November 17th 1881, which publicly promised the three laws on accident, health, retirement and invalidity insurance, claimed: ${ }^{25}$ "The healing of social damage will not be found exclusively in the repression of social democratic rioting, but rather steadily in the positive advancement of the workers well-being." At the same time, the protestant Prussian administration of course still judged the catholic movement as major enemy of the Reich. Protestantism and social policy are very closely linked in the Prussian case. ${ }^{26}$

22 Cf. Jörg Vögele, Urban mortality change in England and Germany, 1870-1913 (Liverpool, 1998), pp. 150-189; Jörg Vögele, Wolfgang Woelk eds., Stadt, Krankheit und Tod: Geschichte der städtischen Gesundheitsverhältnisse während der epidemiologischen Transition (vom 18. bis ins frühe 20. Jahrhundert) (Berlin, 2000).

23 Wolfgang Ayaß, "Bismarck und der Arbeiterschutz", in Vierteljahrschrift für Sozialund Wirtschaftsgeschichte 89 (2002), pp. 400-426.

24 Hans-Peter Ullmann, Das Deutsche Kaiserreich 1871-1914 (Frankfurt/M., 1995), pp. 14-31, pp. 173-181; Heinrich August Winkler, Der lange Weg nach Westen. Deutsche Geschichte 1806-1933 (Bonn, 2002), pp. 247-257; Wolfgang Reinhard, Geschichte der Staatsgewalt. Eine vergleichende Verfassungsgeschichte Europas von den Anfängen bis zur Gegenwart (Munich, 1999), pp. 458-479.

25 Florian Tennstedt, "Vorgeschichte und Entstehung der Kaiserlichen Botschaft vom 17. November 1881", in Zeitschrift für Sozialreform 27 (1981), pp. 663-710, quotation p. 732/33 (translation by FD); Quellensammlung zur Geschichte der deutschen Sozialpolitik 1867 bis 1914. II. Abt.: Von der kaiserlichen Sozialbotschaft bis zu den Februarerlassen Wilhelms II. (1881-1890). Vol. 1: Grundfragen der Sozialpolitik. Die Diskussion der Arbeiterfrage auf Regierungsseite und in der Öffentlichkeit (Darmstadt, 2003).

26 Jochen-Christoph Kaiser, Martin Greschat, eds., Sozialer Protestantismus und Sozialstaat. Diakonie und Wohlfahrtspflege in Deutschland 1890 bis 1938 (Stuttgart, 1996); HeinzGerhard Haupt, Dieter Langewiesche, eds., Nation und Religion in der deutschen Geschichte (Frankfurt/M., 2001); Norbert Friedrich, Traugott Jähnichen, eds., Sozialer Protestantismus im Kaiserreich (Münster, 2005). 
The Prussian-German introduction of social insurance was implemented by means of three laws in the 1880 ies. The law on accident insurance enacted in 1884 represents the central piece of the legislation and consequently was the most controversial. The negotiations got more disimpassioned when the waiting period after an accident and before starting benefits to the injured was suddenly extended from 14 days to 13 weeks. This happened definitely against the instructions of Chancellor Bismarck. As a result, in 1883 health insurance was invented to bridge the time gap of 13 weeks. The main issue of German health insurance was to politically enable accident insurance and not to improve workers' - not to speak of "public" - health system. With the passage of the invalidity and the retirement insurance laws in 1889, the legislative part of the reform of social insurance was completed. $^{27}$

Different political objectives of this legislation are to mention and health care did not feature prominently among them. It intended to keep the insured factory workers from abject impoverishment in case of accident, illness or old age, and to relieve the municipal poor relief burdens on a second level. The social democrats voted against this law as the health insurance pointed directly to the inclusion of their constituency. Initially, the focus was on compensation for the loss of earnings in case of illness after the fourth day of incapacity to the amount of half the average of a local wage for a day. Medical treatment, medication and, under certain circumstances, admission to a hospital, had been the secondary purpose. But until the First World War the health insurance developed into an institution primarily financing medical services for the insured, thus becoming detached from poor relief in terms both of organisation and intention.

The health insurance companies were financed by premiums paid two-thirds by the employees and one-third by the employers. With the health insurance companies a completely new actor appeared in the field of health care politics. Internally, they served to balance the interests of employees and employers which shared the independent insurance administrations according to a ratio of two-thirds by the employees and one-third by the employers; externally, they were powerful representatives of their members' vis-à-vis the state, the municipalities, and the suppliers of medical services, particularly doctors. This "German" model of health care provision by compulsory insurance refers to the conservative model of social pacification which seeks to establish an authoritarian, monarchist welfare state by

27 Florian Tennstedt, Heidi Winter, “'Der Staat hat wenig Liebe - activ wie passiv'. Die Anfänge des Sozialstaats im Deutschen Reich von 1871“, in Zeitschrift für Sozialreform 39 (1993), pp. 362-392; Florian Tennstedt, Heidi Winter, “'Jeder Tag hat seine eigenen Sorgen, und es ist nicht weise, die Sorgen der Zukunft freiwillig auf die Gegenwart zu übernehmen.' Die Anfänge des Sozialstaates im Deutschen Reich von 1871“, in Zeitschrift für Sozialreform 41 (1995), pp. 671-706. 
Figure 2. Insurance members in percent of population.

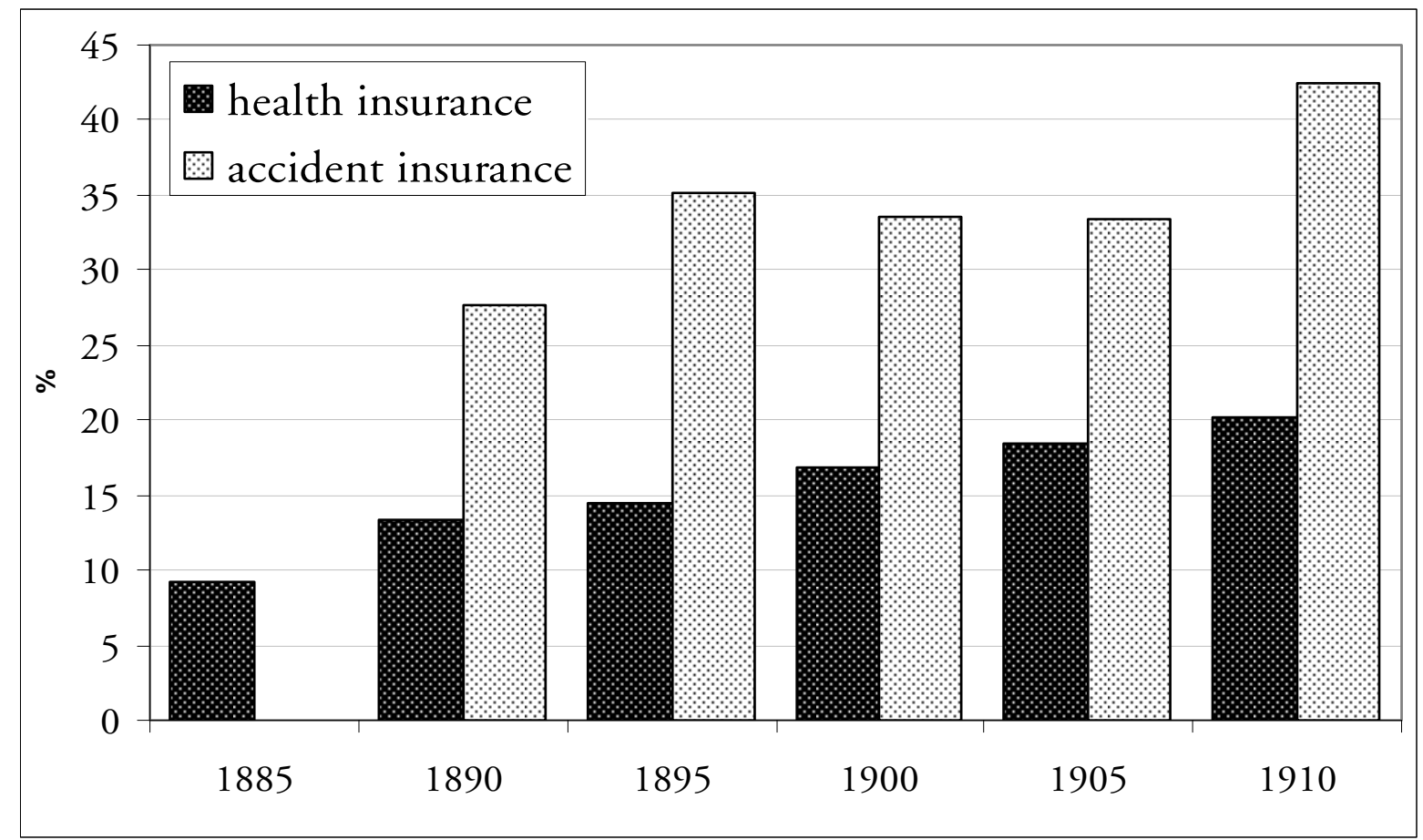

Source: Gerd Hohorst, Jürgen Kocka, Gerhard A. Ritter, Sozialgeschichtliches Arbeitsbuch. Vol. 2: Materialien zur Statistik des Kaiserreichs 1870-1914. (2nd Ed. Munich, 1978), p. 22, p. 154/55 (All data relate to the German Reich, not to Prussia.).

supporting a way of balancing social antagonisms in self-administrated organisations under public law outside the parliamentary bodies of political representation.

The insured workers obtained rights to benefits which were uniformly laid down by law. As premium-paying members, workers participated in insurance administration. Thus, to receive benefits from the health insurance system was freed from the discriminating proceeding of public welfare by municipal poor relief, which until 1908 meant the loss of several civil rights, e.g. voting rights. Poor relief, which continued to be administered primarily on a communal level, did not become obsolete, not only as supplementary to the very low benefits of health and retirement insurance. Since the duration of health insurance payments was limited, illness remained the most common factor of poverty. A specific division of responsibilities developed between social insurance on the one hand and welfare care/poor relief on the other - which to overcome is one of the major aims of nowadays social policy in Germany.

Membership was systematically connected with having a regular job as a worker. Total membership grew relatively slowly, not only because the family members of the insured were excluded until 1911. Only one-fifth of the German population 
participated in health insurance in $1910 .^{28}$ Membership grew faster after the "Reich Insurance Code" (Reichsversicherungsordnung) of 1911. ${ }^{29}$ The laws on health insurance, accident insurance and retirement insurance were given an uniform legal frame and compulsory health insurance was extended to salaried employees (Angestellte) - finally to the waste majority of those employed and dependent on wages - as well as family members of the insured. Of course, to include the family members of the insured obviously meant to get the married women into health insurance, which was already anticipated in 1883 and $1892 .{ }^{30}$

Until 1892 supplementary local insurance funds were often favoured by the insured. These funds paid out three-quarters of the average local wages instead of medical treatment. Since an amendment of 1892 structural disadvantages developed vis-à-vis the state health insurance. Thus, the latter developed to a governmental and economical framework primarily financing medical services for the insured individuals in the last decade of the century.

As an immediate effect of health insurance great additional amounts of money were paid for medical treatment within two decades - even if the individual benefits were still low. This could be regarded as the starting point of a modern "medical market place" where prices were dealt between health insurance companies and doctors. Non-academical healing and "alternative" medicine did effectively not profite to an amount which represents its sympathies in the population; ${ }^{31}$ from the 1880 ies onwards the professionalised, academic medicine dominated the market of medical treatment more than ever before, even if medical treatment by doctors still legally was regarded as a trade like others, which to overcome was already one of the major aims of the early doctors' associations. At the same time, the benefits paid out to the insured were constantly increasing.

To give a rough overview, one could compare the benefits per member with the average income. Although the highly aggregated data does not allow a detailed analysis, it becomes clear, that health insurance benefits per member had nearly tripled until the First World War while the average annual income only doubled. Thus, even the insured individuals could have regarded the system as a successful one considering the rising amounts of benefits, and in consequence, the rising chances to obtain medical treatment in case of need.

28 Gerd Hohorst, Jürgen Kocka, Gerhard A. Ritter, Sozialgeschichtliches Arbeitsbuch. Vol. 2: Materialien zur Statistik des Kaiserreichs 1870-1914 (2nd ed. Munich, 1978), p. 22, p. 154, p. 155 .

29 Reichs-Gesetzblatt 1911, pp. 509-860; Versicherungsgesetz für Angestellte, 20. Dezember 1911, Reichs-Gesetzblatt 1911, pp. 976-985.

30 Gesetz betreffend die Krankenversicherung für Arbeiter, 15. Juni 1883, paragraph 21; Gesetz über die Abänderung des Gesetzes betreffend die Krankenversicherung der Arbeiter, 10. April 1892.

31 Martin Dinges, ed., Medizinkritische Bewegungen im Deutschen Reich ca. 1870-1933 (Stuttgart, 1996). 
Figure 3. Health insurance benefits per member and average income.

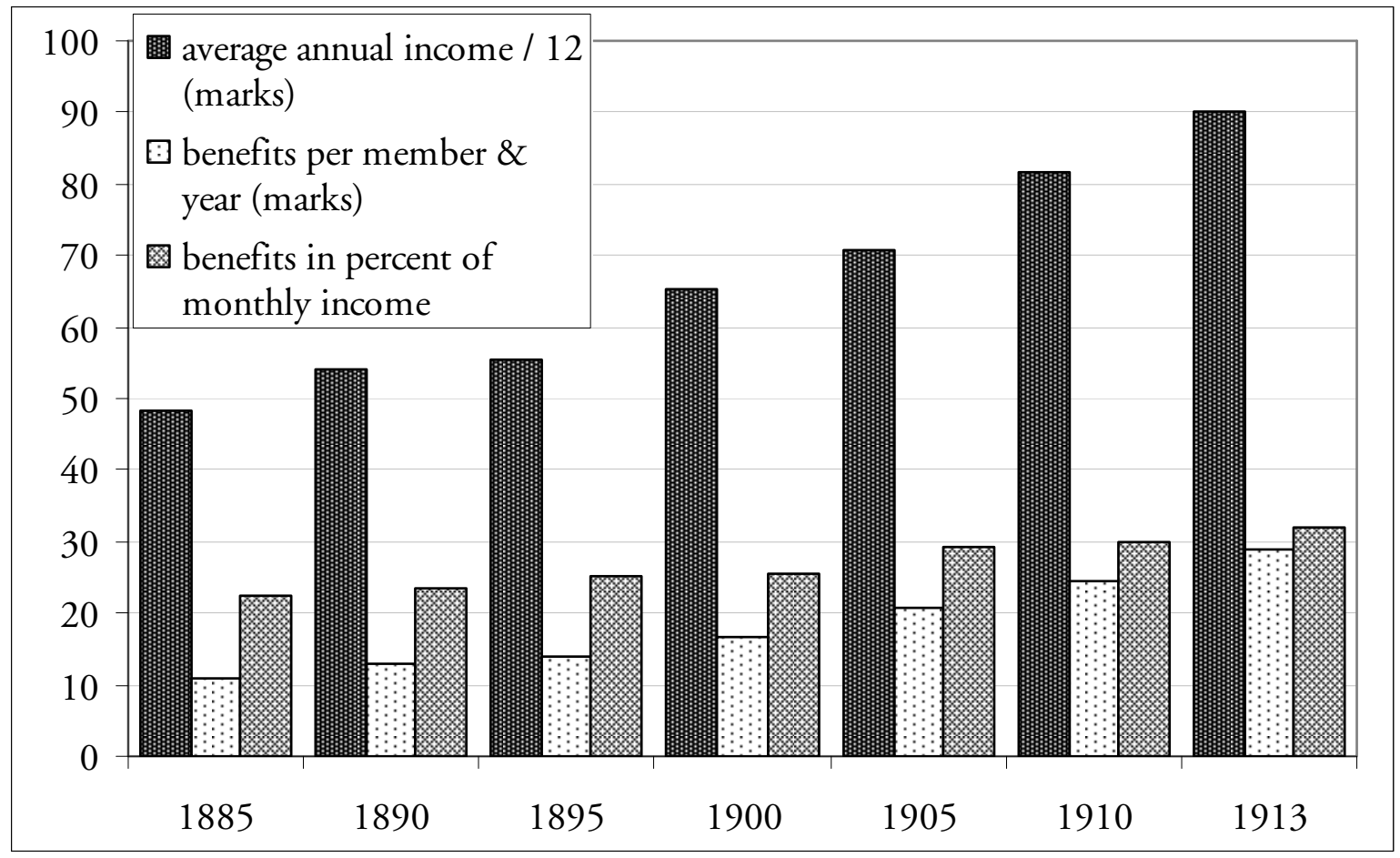

Source: Gerd Hohorst, Jürgen Kocka, Gerhard A. Ritter, Sozialgeschichtliches Arbeitsbuch. Vol. 2: Materialien zur Statistik des Kaiserreichs 1870-1914. (2nd Ed. Munich, 1978), p. 107, p. 154 (All data relate to the German Reich, not to Prussia.).

Finally, there is at least chronological evidence of some kind of connection between new strategies in public health policy and the process of epidemiologic transition. ${ }^{32}$ Mortality was already decreasing in different regions of Germany during the late 18th and the early 19th centuries. ${ }^{33}$ Although the actual crude death rates remained high, there were only a few years in many German regions in the late 18th century in which the number of deaths exceeded the number of births. Such mortality crises visibly disappeared, and the annual fluctuations of mortality were significantly; the average mortality rate declined in numerous parts of Germany. Around the middle of the 19th century, the long-term decline of mortality was interrupted, and between the 1830 ies and the 1880 ies, mortality rates remained relatively high. Since the late 1870ies, the long-term development of mortality was marked by a drastic downward trend. In this respect, the secular change of mortality in the German

32 Cf. Jörg Vögele, Urban mortality change in England and Germany, 1870-1913 (Liverpool, 1998); Jörg Vögele, Wolfgang Woelk eds., Stadt, Krankheit und Tod: Geschichte der städtischen Gesundheitsverhältnisse während der epidemiologischen Transition (vom 18. bis ins frühe 20. Jahrhundert) (Berlin, 2000).

33 William R. Lee, "The Mechanism of Mortality Change in Germany, 1750-1850", in Medizinhistorisches Journal 15 (1980), pp. 244-288; Peter Marschalck, Bevölkerungsgeschichte Deutschlands im 19. und 20. Jahrhundert (Frankfurt/M., 1984); Arthur E. Imhof, Lebenserwartungen in Deutschland vom 17. bis 19. Jahrhundert (Weinheim, 1990). 
"Kaiserreich" in a phase of accelerated industrialisation and urbanisation, was a major step in the epidemiologic transition towards the modern state of health.

Historical epidemiology approved that the decline of infant mortality could be named as one of the major factors of the transitory process, when the traditional mortality situation with the predominance of diseases and low life-expectation turned to the modern situation with high life-expectation and dominating degenerative causes of death. Furthermore it is possible to identify several determinants of the remarkable decline of infant mortality. But for sure there is no one-way dependency which would allow for weighing the significance in a statistically precise manner.

Trying to assess the impact of workers' social insurance one could wonder if there was any impact at all as social insurance of the Bismarck-era did not include the care for mothers and their (new-born) children. But already in the first decades until the First World War health insurance as well as accident insurance and retirement insurance had remarkable effects in disencumbering the municipal poor relief funds. In consequence, communal welfare was freed to broaden its activities, e.g. in the field of mother and child care.

By the end of the 19th century, however, the decrease of birth rates prompted the fear that Germany's future was endangered, from an economic and military point of view. In particular, the direct comparison with England and France provoked hectic activities in the realms of industry and politics. The supply of adequate milk was considered a central municipal responsibility, and infant welfare societies spread after the turn of the century. ${ }^{34}$ Infant welfare centres were founded, particularly in larger towns, with the specific aim to increase breastfeeding rates. It is, however, apparent that infant mortality is decreasing with rising standard of living in general. In the highly industrialised regions of western Germany the differences in infant mortality rates between breast-fed and bottle-fed children steadily disappeared. ${ }^{35}$

34 Paul Weindling, Health, Race and German Politics between National Unification and Nazism, 1870-1945 (Cambridge, 1989), pp. 206-209; Silke Fehlemann, Armutsrisiko Mutterschaft: Mütter- und Säuglingsfürsorge im Deutschen Reich 1890-1924, Phil. Diss. Düsseldorf 2004 (in print); Silke Fehlemann, Wolfgang Woelk, "Der 'Wiedergesundungsprozess des deutschen Menschen'. Zum Verhältnis von Gesundheit, Hygiene und Gesellschaft auf der Düsseldorfer Gesolei”, in: Hans Körner, Angela Stercken, eds., 1926-2002 Kunst, Sport und Körper ( Düsseldorf / Ostfildern-Ruit 2002), pp. 186-192.

35 Jörg Vögele, Urban mortality change in England and Germany, 1870-1913 (Liverpool, 1998), pp. 119-135; Jörg Vögele, Wolfgang Woelk, Silke Fehlemann, "Decline of the Urban Penalty: Milk Supply and Infant Welfare Centres in Germany, 1890s to 1920s", in: Helen Power, Sally Sheard, eds., Body and City: Histories of Urban Public Health (Aldershot 2002), pp. 194-213. 


\section{Summary}

Based on the discourse on poverty of the Reformation era, the late absolutist Prussian state formulated the idea of an absolutist "welfare state" which cares for its poor subjects by obligating the communes and local authorities to concrete measures in fighting beggary and supporting the "deserving" poor. Within the process of industrialisation and urbanisation the local organisations of poor relief and health care for the poor became the longer the more incapable to manage the risk of impoverishment by miserable health conditions of a migrating labour population. At the same time a continuously growing number of legal regulations became in different ways attached to health care provision of the population: poor relief regulations, municipal codes, hygiene / sanitary regulations and the Industrial Code are to be named firstly.

Several early models of insurance, usually locally based and regionally differing came into existence: Hospital insurance funds were connected to a precise single hospital and allowed their members free hospital treatment for a regularly paid premium. As these, early mutual aid associations to support handicraftsmen organised outside or beneath the trade guilds like associative health insurance as well as burial funds were voluntary, completely based on (occasional) payments of their members, without any governmental regulation or support. In the middle of the century, some municipalities began to force migrating labourmen and factory workers to join local insurance funds before admitting their establishment in order to protect the municipal poor relief funds. At the same time the Prussian state began to set up a legal framework for these funds. The main goal of all of these, besides the hospital funds, was not medical treatment but to protect their volunteer members from impoverishment by illness causing incapability to work and avoiding unexpected expenditures of the municipal poor relief agencies respectively. In consequence, their benefits were intended to substitute the loss of earnings in the period of illness and not to pay doctors or medication.

Municipal as well as state poor relief and health care provision policy changed in the last third of the 19th century. The cities and towns by cooperation with bourgeois welfare associations developed into communal welfare agencies providing water supply, waste-water management, mother and child centres as well as tuberculosis consultation and municipal hospital services to name just the most important. The state developed social insurance by means of legislation and, secondly, financial support. The political objective has to be understood in the framework of labour and not least confessional politics intended to support the "internal foundation of the Reich". Introduction of health insurance in 1883 in the very first instance served to hit the Gordian knot of legal principles which obstructed a successful implementation of accident insurance. Within a decade the primordial goal to substitute the loss of earnings in case of illness transformed into 
effective medical healing. Since the 1890ies health insurance changed into a powerful agency to finance medical services. Thus in the long run the balance of demand and supply of medical treatment was restructured in favour of doctors, hospitals and academic medicine. Medical help became affordable for a growing number of people, who would not have asked for a doctor otherwise. To obtain benefits was strictly detached from every form of poor relief because the legally fixed benefits of the insurance corresponded to legally fixed rights of the insured in case of need.

As an economical effect, the growing demand of medical services led to a growing supply, offering the longer the more specialised medical treatment. At the same time, on the communal level, municipal services could broaden and differentiate their offers with respect to diverse advisory activities, especially mother and child welfare care including milk supply, but also municipal hospital services which around the turn of the century became dominating in Germany. This was enabled by freeing the municipal poor relief funds from the older duties and responsibilities to a degree not to be underestimated.

Finally, one has to state that we actually know very little on the immediate consequences of social insurance at the countryside. The effects may be weak as the introduction of labourers' insurance changed social security parameters especially for the urban lower classes. But there should have been at least some indirect and collateral effects (e.g. on migration) which to know would be helpful to better understand the whole complex. Germany was a widely rural country in 1910, when still half of the population lived in communities with less than 5,000 inhabitants.

Fritz Dross, PhD, is Assistant Professor at the Institute for History of Medicine and Medical Ethics, Friedrich-Alexander-Universität Erlangen-Nürnberg, Germany. Email address: Fritz.Dross@gesch.med.uni-erlangen.de. 